Note

\section{A Plate Culture Method for the Simultaneous Detection of Bacteria Producing Pullulan- and/or Starch-Hydrolyzing Enzymes}

\section{Mutsuo Kanno and Eijiro Tomimura}

\author{
Nakatani Memorial Laboratory, \\ CPC Japan Ltd., \\ Chiyoda-ku, Tokyo 102, Japan
}

Received November 16, 1984

Only limited information is available to date on plate culture methods specific for the detection of pullulandegrading microbes. Morgan et al. ${ }^{1)}$ developed an effective method for this purpose, involving the precipitation of pullulan with ethanol. This method, however, seems to be inconvenient for direct isolation of intact cells because the colonies on the plate medium are exposed to ethanol for $2 \sim 5 \mathrm{hr}$ in order to visualize pullulanase-originating transparent halos.

In this communication, we report a new method which can be used for detection and direct isolation of microbe producers of pullulan-hydrolyzing enzymes. Moreover, simultaneously this method can also distinguish two other types of microbes; one which produces amylase and another which produces both amylase and pullulanhydrolyzing enzymes.

A blue-colored amylose and a red-colored pullulan were prepared by means of covalent bonding of the substrates with reactive dyestuffs, according to the method reported by Rinderknecht et al. ${ }^{2}$ Remazol Brilliant Blue R (Sigma Chemical Co., Mo., U.S.A.) and Mikacion Brilliant Red 5BS (Mitsubishi Chemical Industries Ltd., Japan) were used as the blue and red dyestuffs. The plate medium consisted of $(\%, \mathrm{w} / \mathrm{v}): 2.0$ agar (Difco Laboratories, Mich., U.S.A.), 1.0 soluble starch, 0.2 blue-colored amylose, 0.1 red-colored pullulan, 0.1 yeast extract (Oxoid Ltd., England), 0.2 Bacto-tryptone (Difco), $0.02 \mathrm{CaCl}_{2} \cdot 2 \mathrm{H}_{2} \mathrm{O}$, $0.02 \quad \mathrm{MgSO}_{4} \cdot 7 \mathrm{H}_{2} \mathrm{O}, \quad 0.0001 \quad \mathrm{MnCl}_{2} \cdot 4 \mathrm{H}_{2} \mathrm{O}, \quad 0.001$ $\mathrm{FeSO}_{4} \cdot 7 \mathrm{H}_{2} \mathrm{O}, 0.03 \mathrm{KH}_{2} \mathrm{PO}_{4}$ and $0.1\left(\mathrm{NH}_{4}\right)_{2} \mathrm{SO}_{4}$. The medium $\mathrm{pH}$ was adjusted to 6.0 or 4.0 (for the isolation of acidophilic bacteria) by adding the necessary amounts of $0.2 \mathrm{~N}$ or $2 \mathrm{~N}$ sulfuric acid to the medium, which had been autoclaved and cooled to around $60^{\circ} \mathrm{C}$.

The colors of the blue amylose and red pullulan in the plate medium disappear as a result of their hydrolysis by $\alpha$ amylase and pullulanase, respectively. Therefore, with the purple-colored medium (obtained on combined use of the two substrates), the formation of red and blue zones occurs around the colonies of microbes which produce $\alpha$ amylase and pullulanase, respectively. In addition, a colony which produces both $\alpha$-amylase and pullulanase forms a clear zone. The usefulness of this method has been confirmed through our recent work on the isolation of thermophilic microbes under aerobic and anaerobic, and neutral and acidic conditions. The following is a part of the results for thermophilic aerobic bacteria.

A suitably diluted soil sample was poured on the plate

Table I. An Example of the Screening Work

\begin{tabular}{|c|c|c|c|c|c|}
\hline \multirow{2}{*}{$\begin{array}{l}\text { Isolation } \\
\text { marker }^{a}\end{array}$} & \multirow{2}{*}{ Strain } & \multicolumn{2}{|c|}{ Growth range ${ }^{b}$} & \multicolumn{2}{|c|}{ Hydrolyzing activities $(\mathrm{U} / \mathrm{ml})$ toward: } \\
\hline & & $T\left({ }^{\circ} \mathrm{C}\right)$ & $\mathrm{pH}$ & Soluble starch & Pullulan \\
\hline \multicolumn{6}{|l|}{ Red zone } \\
\hline & A-2* & $43 \sim 70$ & $2.0 \sim 6.0$ & 200 & 0 \\
\hline & A-4* & $(60)$ & (4) & 50 & 0 \\
\hline & D-16** & (60) & (4) & 980 & 0 \\
\hline \multicolumn{6}{|l|}{ Blue zone } \\
\hline & D-11* & $40 \sim 65$ & $5.0 \sim 8.0$ & 0 & 0.04 \\
\hline & D-20* & $40 \sim 70$ & $5.0 \sim 8.5$ & 0 & 0.24 \\
\hline & D- $21 *$ & $45 \sim 70$ & $5.5 \sim 9.0$ & 0 & 0.03 \\
\hline \multicolumn{6}{|l|}{ Clear zone } \\
\hline & D-1* & $35 \sim 60$ & $2.2 \sim 5.4$ & 15 & 0.15 \\
\hline & D-10* & $40 \sim 60$ & $2.5 \sim 5.5$ & 30 & 0.30 \\
\hline & D-18** & $(60)$ & (4) & 1200 & 2.0 \\
\hline
\end{tabular}

a Changes in color around colonies growing on the purple-colored plate medium, see text.

$b$ Growth after $24 \mathrm{hr}$ in a liquid medium containing (\%,w/v) 1.0 glucose, 0.1 yeast extract (Oxoid), 0.2 Bactotryptone (Difco) and mineral salts. Figures in parentheses indicate the isolation conditions.

* Aerobic thermophilic bacteria.

** Thermophilic ray fungi, isolated through the screening work by chance. 
medium ( $\mathrm{pH} 6.0$ or 4.0 ) and cultured at $60^{\circ} \mathrm{C}$ for $1 \sim 2$ days. Colonies showing a red, blue or clear zone around them were isolated, inoculated into a flask medium $\left(50 \mathrm{ml} / 500-\mathrm{ml}\right.$ flask) and cultured at $50^{\circ} \mathrm{C}$ for 2 days on a rotary shaker $(300 \mathrm{rpm})$. The flask medium consisted of $(\%, \mathrm{w} / \mathrm{v}): 3.0$ soluble starch, 0.5 yeast extract (Oxoid), 2.5 "Proflo" (a powdered cotton seed germ; Traders Protein Division, Texas, U.S.A.), $0.06 \mathrm{CaCl}_{2} \cdot 2 \mathrm{H}_{2} \mathrm{O}, \quad 0.05$ $\mathrm{MgSO}_{4} \cdot 7 \mathrm{H}_{2} \mathrm{O}, 0.001 \mathrm{MnCl}_{2} \cdot 4 \mathrm{H}_{2} \mathrm{O}, 0.13 \mathrm{KH}_{2} \mathrm{PO}_{4}$ and 1.0 $\left(\mathrm{NH}_{4}\right)_{2} \mathrm{SO}_{4}$. The $\mathrm{pH}$ was adjusted to 6.5 (for $\mathrm{pH}$ 6-isolates) or 5.0 (for $\mathrm{pH} 4$-isolates) after autoclaving. The amylase activities in the culture filtrates were assayed at $60^{\circ} \mathrm{C}$ for $10 \mathrm{~min}$ in $0.2 \mathrm{M}$ sodium acetate buffer ( $\mathrm{pH} 4.5$ ) according to the method of Fuwa, ${ }^{3 !}$ with a slight modification, $0.2 \%$ soluble starch (Junsei Chemical Co., Ltd., Japan) was used as the substrate. One unit of amylase was defined as the amount of enzyme which catalyzed a $10 \%$ decrease in the blue value per min. For the determination of pullulanhydrolyzing activities, an aliquot of the culture filtrate was added to $1 \%$ pullulan (PF 20, Hayashibara Co., Ltd., Japan) solution in $0.02 \mathrm{M}$ sodium acetate buffer, $\mathrm{pH} 4.5$. After incubation at $60^{\circ} \mathrm{C}$ for $60 \mathrm{~min}$, the reducing sugars produced were determined by the alkaline ferricyanide method, ${ }^{4}$ with a slight modificaion. One unit of pullulanhydrolyzing enzyme was defined as the amount of enzyme which produced reducing sugar equivalent to one mol of glucose per $\min .^{5,6)}$
An example of the results of the screening work is shown in Table I. Throughout this work, all the bacterial isolates which formed a blue zone around their colonies produced pullulan-hydrolyzing enzymes, with no amylase activities. The red zone-forming isolates produced only amylase. Likewise, the clear zone-formers produced both pullulan-hydrolyzing enzymes and amylase. The clearzone- and red-zone-formers were found to be common amongst both acidophilic and ordinary (neutral growth $\mathrm{pH})$ thermophiles. The blue-zone-formers, on the other hand, were found mainly amongst ordinary thermophiles, but at a low frequency. No inhibitory effects of the red and blue dyestuffs were observed on the bacterial growth.

\section{REFERENCES}

1) F. J. Morgan, K. R. Adams and F. G. Priest, J. Appl. Bacteriol., 46, 291 (1979).

2) H. Rinderknecht, P. Wilding and B. J. Haverback, Experientia, 23, 805 (1967).

3) H. Fuwa, J. Biochem., 41, 583 (1954).

4) O. Schales and S. S. Schales, Arch. Biochem. Biophys., 8, 285 (1945).

5) B. E. Norman, Starch/Stärke, 34, 340 (1982).

6) Y. Suzuki and M. Chishiro, Eur. J. Appl. Microbiol. Biotechnol., 17, 24 (1983). 